\title{
An Investigation of Competitive Priorities and competitive Advantage among small scale industries with reference to Coimbatore city
}

\author{
${ }^{1}$ Ms.P.Kavitha, ${ }^{2}$ Mr.P.Karthikeyan, ${ }^{3}$ Ms.N.Devi, \\ ${ }^{l}$ Head of Department, Department of Management studies, Kalaingar Karunanidhi Institute of Technology, \\ Coimbatore. \\ ${ }^{2}$ Assistant Professor, Department of Management studies, Kalaingar Karunanidhi Institute of Technology, \\ Coimbatore. \\ ${ }^{3}$ Assistant Professor Department of Management studies Kurinji College of engineering and Technology, \\ Trichy.
}

\begin{abstract}
In this paper, the authors examine the relationship between the competitive priorities and competitive advantage among small scale industries in Coimbatore. The data set were randomly drawn from a sample of 22 top level executives of small scale industries in Coimbatore to draw valid conclusions. To measure the competitive advantage and competitive priorities of small scale industries, we considered 13 and 32 keys as determining variables, respectively. The ranking on a five point Likert scale regarding competitive priorities in small scale industries were measured based on the domains such as Quality,Cost, Delivery, flexibility, Customer-focus and Know-how. Also, the same scale is used for competitive advantage; we employed Cronbach's alpha test and multiple regression analysis. The results suggest that there is a significant relationship between the competitive priorities and competitive priorities and competitive advantage among the small scale industries in Coimbatore.

Keywords: Small Scale industries, Competitive Priorities, Competitive Advantage, Cronbach's Alpha Test, Multiple Regression Analysis
\end{abstract}

\section{Introduction}

Business strategies are formulated to determine the way in which the organizations can move from their present competitive position to a newer and a strong one. As a result of the research, the competitiveness means different thing to different organizations. Some organizations sight competitiveness as the ability to persuade customers to select their offerings over alternatives while some others view competitiveness as the ability to improve process capabilities continuously. Michael Porter (1985) ${ }^{1}$ explained Competitive advantage grows out of value a firm is able to create for its buyers that exceeds the firm's cost of creating it. Value is what buyers are willing to pay, and superior value stems from offering lower prices than competitors for equivalent benefits or providing unique benefits that more than offset a higher price. There are two basic types of competitive advantage cost leadership and differentiation. In today's scenario, throughout the country, globalization and rapid change in technologies have increased an interest on competitive priorities among the small scale industries. Further, these priorities have changed significantly from time to time. Treacy and Wiersema $(1995)^{2}$ offer another popular generic framework for gaining competitive advantage. In their framework, a firm typically will choose to emphasize one of three "value disciplines": product leadership, operational excellence, and customer intimacy. The main change is from cost to quality and eventually to delivery and responsiveness. Competitiveness is a complex subject that has been analyzed by many scholars using different theoretical approaches. Some authors view competitiveness of the firm in terms of productivity or output.

The small scale industries function with strategic priorities is core to competitiveness, the continuous improvement of the small scale function plays a very important role in the pursuit of competitiveness on the long run. Youndt, M.A., Snell, S.A., Dean, J.W. Jr., Lepak, D.P., (1996) ${ }^{3}$. Cluster-analyzed 97 manufacturers across four manufacturing strategies orientations _quality, delivery flexibility, scope flexibility and cost. Competitive priorities might be used as measures of both internal and external competitiveness among the small scale industries. The competitive priority is generally regarded as the dimensionality or content of manufacturing strategy. Competitive priority is generally used in the studies of manufacturing strategy, in

\footnotetext{
${ }^{1}$ Porter, Michael, Competitive Advantage, the Free Press, NY, 1985.

${ }^{2}$ Treacy, M., F. Wiersema, the Discipline of Market Leaders, Addison-Wesley, 1995.

${ }^{3}$ Youndt, M.A., Snell, S.A., Dean, J.W. Jr., Lepak, D.P., 1996. Human resource management, manufacturing strategy and firm performance. Academy of Management Journal 39_4. 836-866.
} 
which, the first and second ranked objectives are quality and delivery performance respectively. Performance results for competitive priorities find out the strategic strengths and weakness at the business unit level. Business strategic strengths/weaknesses are represented by competitive priorities that contribute positively/negatively, to competitive advantage of the company. The

literate review would thus explore the nature of competitiveness and the issues related to the research objective.

\section{Literature Review}

Increased competition in the global market makes the competitive strategy topic more dominant in entrepreneurship and Business. Porter $(1991)^{4}$ defines competitive advantages as the capability of a company or industry to make the products that provide more value to the customer than competing products. Parnell, $(2006)^{5}$ suggest that competitive priorities leads to both better sales and higher profits. Bowman (1974) ${ }^{6}$ says that strategy is about a "continuing search for rent". According to passemard and Kleiner $(2000)^{7}$, the competitive advantage is gained by five sources of innovation which includes: the new technologies, modification of the demand or a new demand, the occurrence of a new segment, the changes in the costs or the availability of means of production and changes in regulation. Competitive strategies try to address the issue of "how" a firm should compete with its competitors in a particular industry This strategy enables a firm to gain competitive advantages and priorities over its rivals Strategies for competitive advantage are explained in various perspectives. A firm is said to have a competitive advantage when it is implementing a value creation strategy which is not simultaneously being implemented by its current or potential competitors. The model which is framed in this research is however, more suitable for a market condition with simple group structures, high concentrations, and rather for homogeneous firms and much less applicable to explain large variations of firm performance in a single industry Competitive advantage arises from the difference among small scale firms on any dimension of attributes and individually that allows one firm to create better customer value and also do something comparably superior than its competitors Meanwhile, generic sources of competitive advantage are include ownership of assets or position, access to distribution and supply, as well as proficiency knowledge of competence and capability in business operations strongly believe that internal competencies are the basis for a firm to be a strong competitor in the market. Real competitive advantage implies that companies are able to satisfy customer needs more effectively than their competitors. It is achieved if and only if actual value is added for customers. Thus, Osman, and Galang, M.C. (2011) ${ }^{8}$ generic strategies in the form of cost leadership, differentiation and market focus may be useful, but inadequate for SMEs to stay competitive. A business must add worth if it is to be successful.

According to Schendel and Hofer $(1979)^{9}$. The essential elements in adding value are.

(1) Understanding and being close to customers, in particular understanding is their perception value (2) a commitment to quality (3) a high all- round service (4) speedy reaction to competitive opportunities and threats. Small organizations which understand their customers can create competitive advantage and so benefit from higher prices and loyalty to customers. Higher capacity of utilization can help to reduce costs.

Skinner $(2011)^{10}$ identified the absence of manufacturing function as a missing link in the corporate strategic planning process. According to his study, manufacturing strategy could be used to exploit certain properties of manufacturing function to achieve competitive advantage. He suggested that a proper fit is essential between the manufacturing and marketing functions. He also found five decision areas for trade-off in manufacturing industry: plant and equipment, production planning and control, labor and staffing; product design; organization management. It is defined by APICS as "A collective pattern of decisions that acts upon the formulation and deployment of small scale resources. To be most effective, the manufacturing strategy should act in support of the overall strategic directions of the business and provide for competitive advantages.

Recent studies found that a firm, which has competencies in many functional areas, would be better able to remain competitive in the market Evans and Lindsay, $(1996)^{11}$. It is advisable that mixed strategies, such as cost reduction, innovation and quality enhancement to be adopted simultaneously to gain domestic and international competitive advantage, regardless of industry

\footnotetext{
${ }^{4}$ Porter (1991) Competitive Strategy: Techniques for Analyzing Industries and Competitors, is in its 63rd printing.

${ }_{5}^{5}$ Parnell, J.A. (2006), "Generic strategies after two decades: a reconceptualization of competitive strategy", Management Decision, Vol. 44 No. 8, pp. $1139-154$.

${ }^{6}$ Bowman, E.H. (1974), “Epistemology, corporate strategy, and academy”, Sloan Management Review, Vol. 15 No. 2, pp. 35-50.

${ }^{7}$ D. Passemard, Brian H. Kleiner, (2000) "Competitive advantage in global industries", Management Research News, Vol. 23 Iss: 7/8, pp.111 - 117

${ }^{8}$ Osman, I., Ho, T.C.F. and Galang, M.C. (2011), “The relationship between human resource practices and firm performance: an empirical assessment of firms in Malaysia”, Business Strategy Series, Vol. 12 No. 1, pp. $41-48$

${ }^{9}$ Schendel, D.E. and Hofer, C.W. (1979), Strategic Management, Little, Brown and Company, Boston.

${ }^{10}$ Skinner W., 2011. Manufacturing- Missing Link in Corporate Strategy. Harvard Business Review May-June, 136-145.

${ }^{11}$ Evans, J.R. and Lindsay, W.M (1996), The Management and Control of Quality, 3rd ed., West Publishing Co., St Paul, MN.
} 
"This paper does not intend to test any hypothesis, but the six resources and capability areas were chosen because they are normally hypothesized or regarded to be significant factors to firm performance. Chaston et al (2001) found that HRM practices, firm management (quality and information) and innovation (new product development) are core competencies and crucial for firm growth.

\section{Competitive Priorities}

Competitive priorities are a symbol of a holistic set of tasks, which should be performed by the manufacturing function in order to support the business strategy. Traditionally, competitive priorities have been considered to be incompatible with one another. Hayes and Wheelwright, 1984. Given the multi-dimensional nature of these priorities, multiple items were used to capture a manufacturer's emphasis on each competitive priority. These items, listed in Appendix A, were taken from several published sources, including Morrison and Roth _1993., Ritzman et al. 1993., Nemetz _1990., Wood et al._1990., and Roth and Miller _1990.. Competitive priorities, generally includes price/cost, quality, dependability and flexibility. Low cost, flexibility, quality and delivery /dependability are four main components of competitive priority. More recently, small scales firms have placed greater importance on flexibility and agility while maintain high performance on dependability, quality, and cost.

Competitiveness of a company generally depends on its ability to perform well in dimensions such as cost, quality, delivery, dependability and speed, innovation and flexibility to adjust itself to variations in demand. Some researches modified the multi-dimensional structure of competitive priority by integrating new items such as innovation and human resources to give emphasis to each competitive goal.

\section{Competitive Priorities and Competitive Advantage}

Considering the argument presented in above literature review, the relationship between competitive priorities and competitive advantage is depicted in figure 1 to meet the research objective presented.

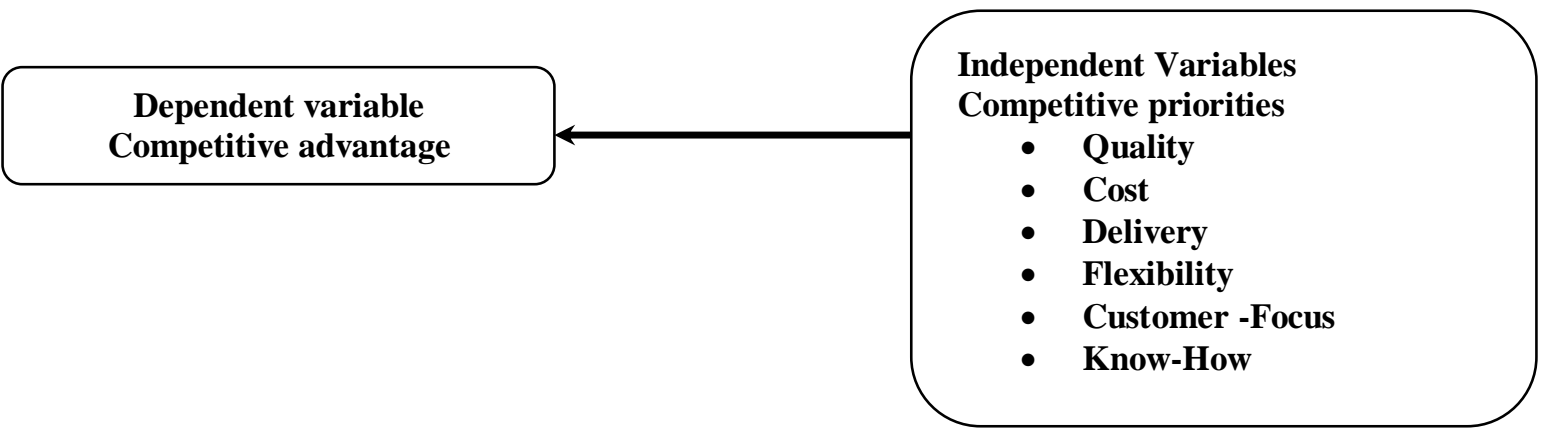

Figure 1: Relationship between competitive priorities and Competitive advantage

\section{OBJECTIVE}

The competitive priority and competitive advantage will differ based on the level of field in which the firm operates. So, new set of competitive priority may emerge and that may lead to different sets of competitive advantage. Coimbatore is unique attractive place for small scale industries to start their business.

The business attractiveness factors are:

$\checkmark$ Government policy and its support

$\checkmark$ Infrastructure

$\checkmark \quad$ Financial assistance and subsidies

$\checkmark \quad$ Skilled and educated work force and

$\checkmark \quad$ Well transport facility connected with air, road and rail etc.

The objective of the research is to investigate the relationship between competitive priorities and competitive advantages of small scale industries in Coimbatore City.

\section{Methodology}

Data were collected using a questionnaire. A well structured questionnaire was developed and it consists of competitive advantage variables and six competitive priority domains. Questionnaires were organized into two sections: (1) Industry profile and (2) to measure the competitive advantage and competitive priorities of small scale industries, we considered 13 and 32 key determining variables, respectively. The scaling performance of competitive priorities in small scale industries were measured through the domains such as Quality, Cost, Delivery, Flexibility, Customer focus and Know-how, along other with the Competitive advantage variables. Five point Likert scale (1- Very low priority, 2- Low priority, 3- Average priority, 4- High 
priority, 5- Very high priority) was used to collect data. Data were collected from participating firms by conducting face-to-face interviews with Chief Executives, Managing Directors, General Managers and Senior Level Managers dealing with a functional area of the organization such as marketing, operations, finance and human resources. Sample data were collected based on sample random of sample method from 22 small scale companies that located in the Coimbatore. For the purpose of analysis, we applied Cronbach alpha test to find the internal consistency reliability of several items in the data and we employed multiple linear regression. SPSS software (Statistical Package program for Social Sciences for windows version 16.0) was used for analyzing the data.

Multiple linear regression analysis deals with problems of estimation having three or more variables. In this problem, we used Ordinary Least Squares technique (OLS). This model allows estimating the relation between a dependent variable and a set of independent variables.

The general form of OLS is given below:

$y_{i}=\alpha_{0}+\beta_{1} x_{1 i}+\beta_{2} x_{2 i}+\beta_{3} x_{3 i}+\ldots \ldots . .+\beta_{n} x_{n i}+\varepsilon_{i} \ldots$

where

$\mathrm{y}_{\mathrm{i}}$ represents dependent variable

$\mathrm{xli}, \mathrm{X}_{2 \mathrm{i}}, \mathrm{X}_{3 \mathrm{i}}, \ldots \ldots . . \mathrm{X}_{\mathrm{ni}}$ represents independent variables

$\alpha_{0}$ represents intercept

$\beta_{1}, \beta_{2}, \beta_{3}, \ldots \ldots . .+\beta_{\mathrm{n}}$ represents the parameters to be estimated

$\varepsilon_{\mathrm{i}}$ represents the error term

This research is aimed to investigate the relationships between the competitive priorities and competitive advantage of small scale industries in the Coimbatore. In the present research work, competitive advantage is considered as a dependent or outcome variable. The competitive priority domains as independent variables are taken into consideration for this study are given as below:
1. Quality
2. Cost
3. Delivery
4. Flexibility
5. Customer-focus
6. Know-how

The model designed for this particular problem is given below in equation (2);

Competitive advantage $_{i}=\alpha_{0}+\beta_{1}$ Quality $_{i}+\beta_{2}$ Cost $_{i}+\beta_{3}$ Delivery $_{i}+\beta_{4}$ Flexibility $_{i}+\beta_{5}$ Customer-focus $_{i}+\beta_{6}$ Know-how ${ }_{i}+\varepsilon_{i}$

All the measurement scales used in this research was based on existing research. The validity and reliability of the measurement scale used for operational research on this study contains from the supported literature given above. The competitive advantage of small scale industries construct was measured using the measurement scales and indexes included in the earlier work of Molina et.al.(2004), who indicates that the authors have used the following variables to determine firms' level of competitiveness:

1. Market share

2. Profits

3. Returns

4. Technological provision

5. Financial management

6. Quality of products-services

7. After sales services

8. Customer royalty

9. Supplier loyalty

10. Location of establishment

11. Employees' commitment and loyalty

12. Employees' professional know-how

13. Firm's reputation

To find out competitive priorities among factors that determine the competitiveness of small scale industries in the Coimbatore city, the authors have selected domains such as quality, cost, delivery, flexibility, customer focus and know-how. These domains are further broken down into 32 factors as given below:

1. Quality: Factors considered under the domain quality are given as: (1) low-defect rate, (2) performance quality, (3) product durability, (4) environmental aspect, (5) Certification and (6) product reliability.

2. Cost: Factors considered under the domain cost are given as: (1) low costs, (2) value added costs, (3) Continuous improvement, (4) activity based measurement and (5) quality costs.

3. Delivery: Factors considered under the domain delivery are given as: (1) fast delivery, (2) on time delivery, (3) right quality, (4) dependable promises and (5) right amount. 
4. Flexibility: Factors considered under the domain flexibility are given as: (1) design adjustments, (2) broad product line, (3) Ability to rapidly change product mix and (4) Ability to rapidly change production volumes,

5. Customer focus: Factors considered under the domain customer- focus are given as: (1) after sales service, (2) product support, (3) dependable promises, (4) measurement of satisfaction, (5) product customization and (6) customer information,

6. Know-how: Factors considered under the domain know-how are given as: (1) creativity, (2) knowledge management, (3) continuous learning, (4)problem solving skills, (5)training/education and (6) research and development.

\section{Results}

To find out the internal consistency and reliability of data set, we used Cronbach alpha coefficient. Table1 shows score of Cronbach alpha coefficient corresponding to different domains.

Table 1: Results from Cronbachs alpha value corresponding to domains

\begin{tabular}{|l|l|}
\hline Domains & Cronbachs alpha values \\
\hline Competitive advantage & 0.860 \\
\hline Quality & 0.786 \\
\hline Cost & 0.722 \\
\hline Delivery & 0.844 \\
\hline Flexibility & 0.651 \\
\hline Customer-focus & 0.835 \\
\hline Know-how & 0.793 \\
\hline
\end{tabular}

To ensure the reliability of questionnaires this analysis were performed. The recommended minimum acceptable limit of reliability "alpha" for this measurement is 0.60 (Hair et. al. 1998). Table 1 shows that the Cronbach's alpha coefficient of the competitive advantage and competitive priority variables: quality, costs, delivery, flexibility, customer-focus and know-how. The values range from 0.651 to 0.860 which shows that all constructs have passed the reliability test where all alpha-values have exceeded the recommended minimum value of Cronbach's alpha. This indicates that the variables of various domains have good internal consistency. Hence a multiple regression analysis is conducted to test the above objective. The results of multiple regression analysis are presented in Tables 2 .

Table 2: The results of multiple linear regression analysis

\begin{tabular}{|l|l|l|}
\hline Independent Variable & Coefficient & t-value \\
\hline Constant & 0.252 & $(1.35)$ \\
\hline Quality & 0.503 & $(7.10)^{*}$ \\
\hline Cost & 0.282 & $(3.68)^{*}$ \\
\hline Delivery & 0.269 & $(4.59)^{*}$ \\
\hline Flexibility & 0.027 & $(0.47)$ \\
\hline Customer-focus & -0.021 & $(-0.37)$ \\
\hline Know-how & 0.024 & $(0.37)$ \\
\hline R-squared & 0.91 & \\
\hline F-statistic & $83.93^{*}$ \\
\hline
\end{tabular}

Note: (1) Dependent variable is Competitive advantage.

(2) t-statistics are in parenthesis. ${ }^{*}$-significant at one per cent level. ${ }^{* *}$ - significant at five per cent level. ${ }^{* * *}$ significant at Ten per cent level.

\section{Interpretation And Analysis}

With respect to the relationship between the dependent and independent variables, as seen in Table 2, the results emerged from the multiple regression analysis reveals that the coefficient of determination $\mathrm{R}^{2}$ which predicts the relationship between the dependent variable and independent variable is equal to 0.91 . This indication shows that $91 \%$ of the total variance in the dependent variable (competitive advantage construct) is accounted for the independent variables (Quality, Cost, Delivery, Flexibility, Customer-focus, and Know-how). The F-Statistic result shows the overall significance of the model considered for this study as $83.93^{*}$ and it is statistically significant at one per cent level. As shown in Table 2 the empirical result of multiple regression analysis reveals that the variables like Quality, Cost and Delivery are found to be positive and significant at one per cent level. This indicates that the small scale industries in Coimbatore concentrate more on these factors as 
far as its competitive advantage is concerned. The variables like Flexibility and Know-how are found to be positive and statistically insignificant and Customer-focus is found to be negative and statistically insignificant.

\section{Limitations}

The primary limitation on this study is from a limited sample only. Its finding and implications are based on 22 firms that located in Coimbatore. Furthermore, when analyzing all dimensions in this survey, each firm was assigned an equal weightage. This ignores the differences in terms of size, years in business, etc. In addition, participating firms are from all industrial categories. Nevertheless, the initial results appeared to yield useful implications and can later be extended for futures studies.

\section{Conclusion}

This paper investigates the relationship between the competitive priorities and its advantage of small scale industries in Coimbatore. We considered 13 and 32 key determining variables, respectively to measure the competitive advantage and competitive priorities of manufacturing industries and also we employed Cronbach's alpha and multiple regressions to find out the results. Our results suggest that there is a significant relationship between the competitive priorities and competitive advantage among the small scale industries in Coimbatore. According to Abdulkareem (2008) the results of data analysis suggests that there is a significant relationship between the competitive priority and competitive advantage. The results are also in consistent with work presented by Phusavat and Kanchana (2007) where the authors conclude that the quality, customer focus and delivery criteria are recognized as important priorities to improve the manufacturing firm's on competitiveness.

\section{References}

[1] Porter's (1980) American International Journal of Contemporary Research Vol. 2 No. 1; January 2012.

[2] Skinner (2011) "Trade-off? What trade-offs? Competence and competitiveness in manufacturing strategy", California Management Review, summer, pp. 107-22.

[3] Alam, S.S. (2009), “Adoption of internet in Malaysian SMEs”, Journal of Small Business and Enterprise Development, Vol.16 No. 2, pp. $240-55$.

[4] Ahmad, S., Schroeder, R.G. (2002), "Dimensions of competitive priorities: are they clear, communicated and consistent?", Journal of Applied Business Research, Vol. 18 No.1, pp.77-86.

[5] Adam, E. E. Jr. and P. M. Swamidass, “Assessing operations management from a strategic perspective," Journal of Management, Vol. 15, No. 2, pp. 181-203, 1989.

[6] Cleveland, G., Schroeder, R. G. and J. C. Anderson, “A theory of production competence,” Decision Sciences, Vol. 20, No. 4, pp. 655-668, 1989.

[7] Tseng, Mei-Chiun. "Strategic Choice of Flexible Manufacturing Technologies." International Journal of Production Economics 91, no. 3 (2004): 223-227.

[8] Powell, T.C.(1995) "Competitive priorities: Investigating the need for trade-offs in operations strategy", Production and Operations Management, Vol. 11, No. 1, pp. 9-20..

[9] Porter (1991) Competitive Strategy: Techniques for Analyzing Industries and Competitors, is in its 63rd printing.

[10] Parnell, J.A. (2006), "Generic strategies after two decades: a reconceptualization of competitive strategy", Management Decision, Vol. 44 No. 8, pp. 1139-154.

[11] Bowman, E.H. (1974), "Epistemology, corporate strategy, and academy", Sloan Management Review, Vol. 15 No. 2, pp. 35-50.

[12] D. Passemard, Brian H. Kleiner, (2000) "Competitive advantage in global industries", Management Research News, Vol. 23 Iss: 7/8, pp.111- 117

[13] Schendel, D.E. and Hofer, C.W. (1979), Strategic Management, Little, Brown and Company, Boston.

[14] Porter, M.E. (1986), Competitive Strategy, Harvard Business School Press, Boston, MA

[15] Seth, A. and Thomas, H. (1994), "Theories of the firm: implications for strategy research", Journal of Management Studies, Vol. 31, pp. 165-91.

[16] Parnell, J.A (2011), "Strategic capabilities, competitive strategy, and performance among retailers in Argentina, Peru and the United States", Management Decision, Vol. 49 No. 1, pp. 130-55.

[17] Hill, T. J. Manufacturing Strategy - Text and Cases, Burr Ridge; IL: Irwin/McGraw-Hill, 2000.

[18] Parnell, J.A (2011), "Strategic capabilities, competitive strategy, and performance among retailers in Argentina, Peru and the United States", Management Decision, Vol. 49 No. 1, pp. 130-55.

[19] Osman, I., Ho, T.C.F. and Galang, M.C. (2011), "The relationship between human resource practices and firm performance: an empirical assessment of firms in Malaysia”, Business Strategy Series, Vol. 12 No. 1, pp. 41-48.

[20] Skinner W., 2011. Manufacturing- Missing Link in Corporate Strategy. Harvard Business Review May-June, 136-145.

[21] Evans, J.R. and Lindsay, W.M (1996), The Management and Control of Quality, 3rd ed., West Publishing Co., St Paul, MN.

[22] Jonsson, C. and Devonish, D. (2009), "An exploratory study of competitive strategies among hotels in a small developing Caribbean state”, International Journal of Contemporary Hospitality Management, Vol. 21 No. 4, pp. 491-500.

[23] Malaysia (2010b), "SME Annual Report 2009/10”, available at http://www. smecorp.gov.my/ node/1188 (accessed 5 August 2011).

[24] Conference of Ministers Responsible for Small and Medium-Sized Enterprises (SMEs) Istanbul, Turkey, June 3-5 (available at www.oecd.org/dataoecd/6/12/31919223.pdf 3 July 2011).

[25] Truett, Richard. "Ford's Flexibility Reaps Rich Reward." Automotive News 78, no. 6106 (2004): $17 . \quad$ Read more: http://www.referenceforbusiness.com/management/Ex-Gov/Flexible-Manufacturing.html\#ixzz2Ex4lzVT3 